\title{
Impact of household food insecurity on maternal mental health in Egypt
}

Eman Mahfouz, ${ }^{1}$ Eman Mohammed, ${ }^{1}$ Shaza Alkilany ${ }^{1}$ and Tarek Abdel Rahman ${ }^{1}$

${ }^{1}$ Department of Public Health and Preventive Medicine, Faculty of Medicine, Minia University, Minia, Egypt (Correspondence to: S. Fadel: shazafadel18@ gmail.com).

\begin{abstract}
Background: Food insecurity leads to disturbed eating patterns, hunger or poor nutrition and is strongly correlated with poor mental health.

Aims: To determine the impact of household food insecurity on maternal mental health in a rural population in Egypt.

Methods: This community-based cross-sectional study was conducted in Qulubba Village in Minia Governorate. We interviewed 497 mothers with at least one child, using the Household Food Insecurity Access Scale and Hopkins Symptom Check List-25.

Results: Nearly 70\% of women resided in food-insecure households. Symptoms of anxiety and depression were significantly more common among food-insecure mothers. By logistic regression analysis, household food insecurity, socioeconomic status, husband working abroad and number of children were significant predictors of maternal distress. Mothers with severe food insecurity were approximately 13 times more likely to experience mental distress than were food secure-mothers.

Conclusions: Household food insecurity was associated with an increased likelihood of poor maternal mental health. The study highlights the need for policies to decrease poverty and programmes for screening and addressing food insecurity. Integrating mental health into programmes addressing food insecurity and providing counselling are recommended.

Keywords: food insecurity, hunger, mental health, mothers, rural area.

Citation: Mahfouz EM; Mohammed ES; Alkilany SF; Abdel Rahman TA. Impact of household food insecurity on maternal mental health in Egypt. East Mediterr Health J. 2021;27(4):344-352. https://doi.org/10.26719/2021.27.4.344

Received: 27/11/19; accepted: 29/04/20

Copyright (C) World Health Organization (WHO) 2021. Open Access. Some rights reserved. This work is available under the CC BY-NC-SA 3.0 IGO license (https://creativecommons.org/licenses/by-nc-sa/3.o/igo)
\end{abstract}

\section{Introduction}

Food insecurity is "when people lack secure access to sufficient amounts of safe nutritious food for normal growth and development, and an active meanwhile, healthy life" (1). Most recent estimates suggest that nearly $11 \%$ of the global population continues to lack sufficient food to live active and healthy lives (2).

The health consequences of food insecurity go beyond malnutrition. Food insecurity is indicated as a cause of uncertainty in the household, leading to feelings of stress that in turn lead to symptoms of anxiety and depression which may be related to nutritional deficiency or unhealthy behaviour (3). Acquiring foods in socially unacceptable ways may induce feelings of alienation, powerlessness, or shame about one's position on the social hierarchy, and may lead to increased mental health problems and maladaptive behaviour $(4,5)$.

The problem of food insecurity in Egypt is becoming increasingly challenging as a result of the numerous internal and external pressures that have accumulated over the years (6). In 2016, Egypt suffered from floating the Egyptian currency and a decline in customers' purchasing power as a result of inflation (7). In spite of sharp increases in food prices over the past few years due to the economic recession, there has been no assessment of household food insecurity and its impact on maternal mental health in Egypt. Mothers have borne the responsibility of providing care for their children, after floating of the Egyptian currency.

The objective of this study was to determine the impact of household food insecurity on maternal mental health in a rural population in Qulubba, Minia in Egypt.

\section{Methods}

\section{Study design}

This was a community-based cross-sectional study in a rural area in Qulubba Village, Minia Governorate, Upper Egypt during November 2017 to March 2018. A total of 497 mothers with at least one child were included in the study. Selecting an appropriate checklist for this study was done through EQUATOR (https://www.equator-network.org). The STROBE checklist was used for reporting the study (8). A random sampling method was used to select one of the nine districts of Minia Governorate, and one village was chosen randomly, taking into account that the district had homogeneous characteristics. We used random sampling to select households, which were 
the primary sampling unit. The village was divided into 4 sectors around a prominent landmark in the village ( $\mathrm{Ru}-$ ral Health Unit). From each sector, every other household was selected until the required number of households were visited (129 from 2 sectors and 130 from the other 2 sectors) moving from sector to sector. When there was more than 1 household in a building or compound, a number was assigned to each household and one was chosen randomly. If a household did not meet the eligibility criteria, an adjacent house was taken until we reached the targeted sample size.

\section{Study sample}

A sample size of 518 households was determined to provide $97 \%$ power at the level of $5 \%$ significance, considering the prevalence of poverty in rural Upper Egypt as an indirect indicator of food insecurity (49.4\%) (9), using EPI-INFO 7.2.2.6, and after adding 10\% to guard against nonresponse. We successfully recruited 497 households and the response rate was $95.9 \%$.

\section{Data collection}

Data were collected using a structured questionnaire. Each participant was interviewed during a home visit, the aim of the study was explained, and the answers to the questionnaire were filled in by the researcher. Each interview took $\sim 25$ minutes. The questionnaire included the following measures.

Socioeconomic status (SES) was calculated according to El-Gilany et al. (10), who used a modification of the old scoring system of Fahmy and El-Sherbini (11). SES was classified as very low (score $<35$ ), low (35-41), middle $(42-47)$ and high $(\geq 48)$, depending on the quartiles of the calculated score rather than a fixed point. The Household Food Insecurity Access Scale (HFIAS) was used to evaluate the food insecurity of participants' families. HFIAS was developed by The US Agency for International Development (USAID) and funded by the Food and Nutrition Technical Assistance (FANTA) Project (12). The Arabic version of HFIAS was tested for validity in Lebanon and was found to be a valid and reliable tool to assess HFI (13). HFIAS consists of 9 questions. The score is a continuous measure of the degree of HFI in the past 30 days. The higher the score, the higher the HFI. HFIAS categorizes households into 4 levels of HFI: food secure, and mild, moderately and severely food insecure (12). The Hopkins Symptom Checklist-25 (HSCL-25) is derived from the 90-item Symptom Checklist and measures mental health (14). It is a screening tool designed to detect symptoms of anxiety and depression in the preceding month. It is composed of a 10-item subscale for anxiety and a 15-item subscale for depression, with each item scored on a Likert scale from 1 (not at all) to 4 (extremely). A summary score is calculated by adding all scores and dividing by the number of items. Scores above the cut-off of 1.75 indicate clinically significant distress.

\section{Statistical analysis}

Participants with missing information for key variables were excluded from the analysis. SPSS version 20 (SPSS Inc., Chicago, IL, USA) was used for data entry and analysis. Quantitative data are presented as mean and standard deviation, and qualitative data as frequency distribution. The normality of data was assessed using the Kolmogorov-Smirnov test. The relation of each variable to outcome categories was separately tested by the $\chi^{2}$ or Fisher's exact test for categorical variables, and $t$ test or Mann-Whitney for continuous variables. Multivariate binary logistic regression analysis was also undertaken. $P$ $<0.05$ was considered to indicate statistical significance.

\section{Compliance with ethical standards}

The Community Department and Minia Faculty of Medicine approved this study. All data for the women included in the study were kept confidential. All women included in the study were given a code number before data were entered into the computer system, and this procedure was undertaken by the researchers. Full written, informed consent was obtained from all participants.

\section{Results}

The total sample included 497 women from randomly selected households. The mean HFIAS score was 7.9 (6.5) with a range of $0-25$. Among the studied households, $30.4 \%$ were food secure, while $69.6 \%$ were classified as food insecure: $14.3 \%, 38 \%$ and $17.3 \%$ reported mild, moderate and sever food insecurity, respectively.

Nearly $75 \%$ of studied mothers lived in nuclear families (Table 1). The average family size was 5.96 (2.58) and the mean crowding index was 2.1 (0.9). The number of children cared for by mothers was 2.97 (1.28). The mean household size and crowding index were higher in foodinsecure than food-secure families and the difference was significant $(P=0.003$ and $<0.001$, respectively). The number of families receiving government support was higher among food-insecure $(16.2 \%)$ than food-secure $(7.9 \%)$ families $(P=0.014)$.

A significant association was found between household income and food insecurity. Among foodsecure households, $66.3 \%$ were able to save money and $1.3 \%$ were in debt $(P<0.001)$. Among food-insecure households, $21.4 \%$ were able to save money and $15 \%$ were in debt $(P<0.001)$. There was no significant difference between food-secure and food-insecure groups regarding family type, number of children, and ration card and livestock possession.

The average age of the mothers was 29.1 (5.5) years (Table 2). Nearly $28 \%$ of mothers and $19.7 \%$ of husbands in food-insecure households were illiterate compared to $12.6 \%$ and $6 \%$, respectively, in food-secure households $(P<0.001)$. University graduates and postgraduates accounted for $19.2 \%$ of mothers and $29.1 \%$ of husbands in food-secure households, which were higher than $2.6 \%$ and $5.8 \%$, respectively, in food-insecure households $(P<0.001)$. Nearly $20 \%$ of food-secure mothers were 


\begin{tabular}{|c|c|c|c|c|}
\hline \multirow[t]{2}{*}{ Household characteristics } & $\begin{array}{c}\text { Total } \\
(n=497)\end{array}$ & $\begin{array}{l}\text { Food secure } \\
\qquad(n=151)\end{array}$ & $\begin{array}{l}\text { Food insecure }^{a} \\
\qquad(n=346)\end{array}$ & \multirow[b]{2}{*}{$\begin{array}{c}\mathrm{t} \text { test } \\
\text { P value }\end{array}$} \\
\hline & $\begin{array}{l}\text { Mean (SD) } \\
\text { (range) }\end{array}$ & $\begin{array}{l}\text { Mean (SD) } \\
\text { (range) }\end{array}$ & $\begin{array}{c}\text { Mean (SD) } \\
\text { (range) }\end{array}$ & \\
\hline Household size & $\begin{array}{l}5.96(2.58) \\
(3.0-28.0)\end{array}$ & $\begin{array}{l}5.43(1.76) \\
(3.0-14.0)\end{array}$ & $\begin{array}{l}6.19(2.84) \\
(3.0-28.0)\end{array}$ & $\begin{array}{l}-3.03 \\
0.003\end{array}$ \\
\hline No. of children /mother & $\begin{array}{c}2.97(1.28) \\
(1.0-8.0)\end{array}$ & $\begin{array}{l}2.89(1.16) \\
(1.0-6.0)\end{array}$ & $\begin{array}{l}3.01(1.32) \\
(1.0-8.0)\end{array}$ & $\begin{array}{l}-0.998 \\
0.319\end{array}$ \\
\hline \multirow[t]{2}{*}{ Crowding index } & $\begin{array}{c}2.1(0.9) \\
(0.33-6.0)\end{array}$ & $\begin{array}{l}1.74(0.71) \\
(0.6-4.0)\end{array}$ & $\begin{array}{l}2.32(0.91) \\
(0.33-6.0)\end{array}$ & \multirow{2}{*}{$\begin{array}{c}-6.844 \\
<0.001 \\
\chi^{2} \\
p \text { value }\end{array}$} \\
\hline & $n(\%)$ & $n(\%)$ & $n(\%)$ & \\
\hline \multicolumn{5}{|l|}{ Type of family } \\
\hline Nuclear & $373(75.1 \%)$ & $121(80.1 \%)$ & $252(72.8 \%)$ & \multirow{2}{*}{$\begin{array}{l}2.992 \\
0.084\end{array}$} \\
\hline Extended & $124(24.9 \%)$ & $30(19.9 \%)$ & $094(27.2 \%)$ & \\
\hline Ration card possession & $403(81.1 \%)$ & $125(82.8 \%)$ & $278(80.3 \%)$ & $\begin{array}{l}0.406 \\
0.524\end{array}$ \\
\hline Livestock possession & $280(56.3 \%)$ & $92(60.9 \%)$ & $188(54.3 \%)$ & $\begin{array}{l}1.857 \\
0.173\end{array}$ \\
\hline Governmental support & $68(13.7 \%)$ & $12(7.9 \%)$ & $56(16.2 \%)$ & $\begin{array}{l}6.041 \\
0.014\end{array}$ \\
\hline \multicolumn{5}{|l|}{ Household income } \\
\hline Able to save money & $174(35 \%)$ & $100(66.3 \%)$ & $74(21.4 \%)$ & \multirow{4}{*}{$\begin{array}{l}97.382 \\
<0.001\end{array}$} \\
\hline Meet routine expenses and emergencies & $184(37 \%)$ & $34(22.5 \%)$ & $150(43.4 \%)$ & \\
\hline Just meet routine expenses & $85(17.1 \%)$ & $15(9.9 \%)$ & $70(20.2 \%)$ & \\
\hline In debt & $54(10.9 \%)$ & $2(1.3 \%)$ & $52(15 \%)$ & \\
\hline
\end{tabular}

${ }^{a}$ Category includes mildly, moderately and severely food insecure.

$S D=$ standard deviation.

working compared to $6.4 \%$ in food-insecure households $(P<0.001)$. There were no significant differences between participants from food-secure and food-insecure households regarding age and marital status.

Women in food-insecure households differed significantly from their counterparts in food-secure households in terms of anxiety symptoms, depression symptoms and total HSCL scores (Table 3). In foodsecure households, the median total HSCL score was 1.4 (interquartile range, 1.24-1.68) compared to 1.92 (1.592.28) in food-insecure households $(P<0.001)$. Median scores on the depression and anxiety subscales were also higher among food-insecure mothers $(P<0.001)$. Mental distress was classified into low (36.8\%), middle (31.6\%) and high $(31.6 \%)$ tertiles. The proportions of mental distress categories were significantly associated with food insecurity, showing that the proportion of mothers with high mental distress in food-insecure households (42.2\%) was greater than that in food-secure households (7.3\%) $(P<0.001)$.

Binary logistic regression analysis of the relationship between mental health status and HFI and household characteristics showed that, after adjusting for other factors affecting mental distress, 5 variables (HFI, income, SES, husband working abroad, and number of children) retained their significance in the multivariate model (Table 4). Mothers with severe, moderate or mild food insecurity had greater odds of high levels of mental distress than their counterparts in food-secure households. Mothers from a family in debt had greater odds of mental distress than mothers from families able to save money. Mothers from families with income just to meet routine expenses and mothers from families that could meet routine expenses and emergencies had greater odds of mental distress compared with mothers from families able to save money. Mothers from households with high SES were less likely to experience mental distress than mothers from lower SES households. Mothers with husbands working abroad had lesser odds of mental distress. The number of children a mother had was significantly associated with mental distress. An increase of 1 child in a family was associated with a $23 \%$ increase in the odds of that mother being mentally distressed.

\section{Discussion}

Out of the 497 households in Qulubba, 346 (69.6\%) reported some level of food insecurity, with 71 (14.3\%), 189 (38\%) and $86(17.3 \%)$ categorized as mildly, moderately and severely food-insecure households, respectively. The mean HFIAS score was 7.9 (6.5). However, these results may have overestimated food insecurity because some participants had expectations that the answers would influence their access to government support. 


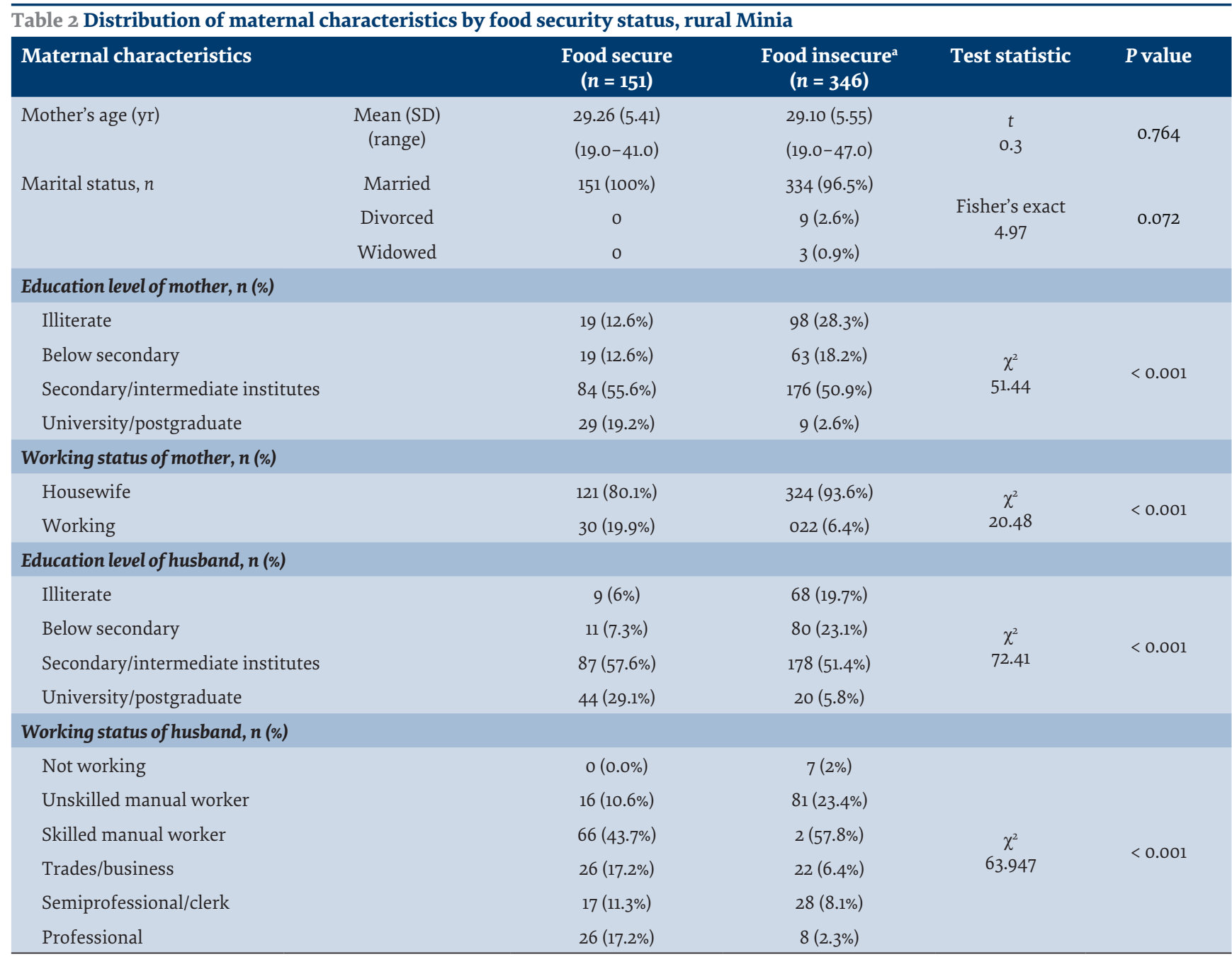

${ }^{a}$ Category includes mildly, moderately and severely food insecure.

$\mathrm{SD}=$ standard deviation.

The level of HFI $(69.6 \%)$ identified in this study was higher than $40 \%$ in Minia and $35.1 \%$ poor dietary diversity of all Egyptians, but lower than $80 \%$ in Assuit, using poor dietary diversity as an indirect indicator for food insecurity. However, in our study, food insecurity was substantially higher than $17.2 \%$, which represented combined food insecurity (poor food consumption in terms of inadequate dietary diversity, calorie deficiency, or both) and income poverty (15). A potential explanation for the higher prevalence of HFI reported in the present study could be the high rate of poverty as demonstrated by the World Food Programme (15), and Minia Governorate has the highest rate of extreme multidimensional poverty, especially in rural areas. Poverty in rural Upper Egypt accounted for $49.4 \%$ (9), which is substantially higher than that in Lebanon (28.6\%) (16) and in Viet Nam $(13.6 \%)(17)$ based on national poverty lines. The latest liberalization of the Egyptian currency could also be a factor in rising food insecurity (18). Another important factor to consider regarding variations is the difference in measurement instruments used, with HFIAS yielding the highest HFI (in a study that used 3 different food access indicators) (19).
In the current study, HFI was not associated with family type, whether nuclear or extended, but rather with family size. Larger households were more likely to be food insecure than small households because increased family size leads to limited income to fulfil the family's needs and to buy adequate and nutritious food. Thus, a lower household income and increased family size tend to worsen HFI (3,20-22).

In the current study, maternal marital status was not associated with HFI, which was in agreement with Ihab et al. (21) but different from Tadesse Tantu et al. (22), who reported that single-head households were 4 times more food insecure. The difference from our study may be attributed to the small number of single-head households.

In the current study, there was a significant association between HFI and educational level of mothers and their husbands. This finding is consistent with Weigel et al. (23). This association may be explained by the fact that higher educational level means a better chance of having a better occupation, good income and better living conditions.

We found an association between HFI level and husbands' employment status. Maternal working status 


\begin{tabular}{|c|c|c|c|c|c|}
\hline \multirow[t]{2}{*}{ Maternal mental health status } & $\begin{array}{c}\text { Total } \\
(n=497)\end{array}$ & $\begin{array}{l}\text { Food secure } \\
\quad(n=151)\end{array}$ & $\begin{array}{l}\text { Food insecure } \\
\quad(n=346)\end{array}$ & \multirow[t]{2}{*}{ Test statistic } & \multirow[t]{2}{*}{$\mathbf{P}$} \\
\hline & $\begin{array}{l}\text { Median } \\
\text { (IQR) }\end{array}$ & $\begin{array}{l}\text { Median } \\
\text { (IQR) }\end{array}$ & $\begin{array}{l}\text { Median } \\
\text { (IQR) }\end{array}$ & & \\
\hline HSCL total score & $\begin{array}{c}1.76 \\
(1.44-2.12)\end{array}$ & $\begin{array}{c}1.40 \\
(1.24-1.68)\end{array}$ & $\begin{array}{c}1.92 \\
(1.59-2.28)\end{array}$ & $\begin{array}{c}\mathrm{U} \\
10381\end{array}$ & $<0.001^{\circ}$ \\
\hline HSCL anxiety score & $\begin{array}{c}1.70 \\
(1.40-2.20)\end{array}$ & $\begin{array}{c}1.40 \\
(1.20-1.80)\end{array}$ & $\begin{array}{c}1.90 \\
(1.60-2.40)\end{array}$ & $\begin{array}{c}\mathrm{U} \\
12354.5\end{array}$ & $<0.001^{2}$ \\
\hline HSCL depression score & $\begin{array}{c}1.73 \\
(1.40-2.13)\end{array}$ & $\begin{array}{c}1.40 \\
(1.20-1.73)\end{array}$ & $\begin{array}{c}1.93 \\
(1.60-2.27)\end{array}$ & $\begin{array}{c}U \\
10898.5\end{array}$ & $<0.001^{a}$ \\
\hline \multicolumn{6}{|l|}{ Probable anxiety (HSCL, anxiety >1.75) } \\
\hline $\begin{array}{l}\text { Yes } \\
\text { No }\end{array}$ & $\begin{array}{l}248(49.9 \%) \\
249(50.1 \%)\end{array}$ & $\begin{array}{l}38(25.2 \%) \\
113(74.8 \%)\end{array}$ & $\begin{array}{l}210(60.7 \%) \\
136(39.3 \%)\end{array}$ & $\begin{array}{c}\chi^{2} \\
53.076\end{array}$ & $<0.001$ \\
\hline \multicolumn{6}{|c|}{ Probable depression (HSCL, depression > 1.75) } \\
\hline $\begin{array}{l}\text { Yes } \\
\text { No }\end{array}$ & $\begin{array}{l}244(49.1 \%) \\
253(50.9 \%)\end{array}$ & $\begin{array}{c}31(20.5 \%) \\
120(79.5 \%)\end{array}$ & $\begin{array}{l}213(61.6 \%) \\
133(38.4 \%)\end{array}$ & $\begin{array}{c}\chi^{2} \\
70.814\end{array}$ & $<0.001$ \\
\hline \multicolumn{6}{|c|}{ Symptomatic HSCL-25 (HSCL, total > 1.75) } \\
\hline $\begin{array}{l}\text { Yes } \\
\text { No }\end{array}$ & $\begin{array}{l}252(50.7 \%) \\
245(49.3 \%)\end{array}$ & $\begin{array}{l}34(22.5 \%) \\
117(77.5 \%)\end{array}$ & $\begin{array}{l}218(63 \%) \\
128(37 \%)\end{array}$ & $\begin{array}{c}\chi^{2} \\
68.948\end{array}$ & $<0.001$ \\
\hline \multicolumn{6}{|l|}{ Mental distress ${ }^{b}$} \\
\hline $\begin{array}{l}\text { Low } \\
\text { Middle } \\
\text { High }\end{array}$ & $\begin{array}{l}183(36.8 \%) \\
157(31.6 \%) \\
157(31.6 \%)\end{array}$ & $\begin{array}{c}97(64.2 \%) \\
43(28.5 \%) \\
11(7.3 \%)\end{array}$ & $\begin{array}{l}86(24.9 \%) \\
114(32.9 \%) \\
146(42.2 \%)\end{array}$ & $\begin{array}{c}\chi^{2} \\
85.506\end{array}$ & $<0.001$ \\
\hline
\end{tabular}

${ }^{a}$ Mann-Whitney test.

${ }^{b}$ Mental distress was classified to low (score $\leq 1.56$ ), middle (score 1.57-2) and high (score > 2) based on tertiles of the HSCL-25.

$\mathrm{HSCL}=$ Hopkins Symptom Check List; IQR = interquartile range.

was also associated with higher prevalence of food security. Generally, working mothers are expected to have better access to food and food security $(22,23)$.

In the present study, there was a high prevalence of symptoms of anxiety and depression among mothers. This finding was similar to that reported by El-Amin et al., who found a high prevalence of common mental distress among mothers attending Minia health centres (24). The current study showed a significant association between food insecurity and poor mental health. With regard to HSCL score, $60.7 \%$ of food-insecure and $25.5 \%$ of food-secure mothers fulfilled the criteria for anxiety symptoms, and $61.6 \%$ versus $20.5 \%$ for depressive symptoms. These findings are consistent with earlier studies in low- and middle-income $(25,26)$ as well as highincome $(27,28)$ countries. Some authors have reported the opposite relationship, with depression leading to food insecurity $(29,30)$. For example, Garg et al. analysed data from the Early Childhood Longitudinal Study Birth Cohort $(n=2917)$ and found that mothers who experienced depression were at greater risk of remaining food insecure over time compared to mothers without depression (29). The association between food insecurity and mental health was addressed in adolescents $(31,32)$. Rani et al. (31) found that teenage girls from food-insecure households are more likely to have high levels of anxiety, depression, loss of behavioural control, and mental distress compared with those living in food-secure households. Other studies have reported a bidirectional association between food insecurity and mental distress (33).

Our model investigating the association between food insecurity and mental health demonstrated that food insecurity, income, SES, husband working abroad and number of children in the household predicted maternal mental distress. In the unadjusted and adjusted models, women who had experienced food insecurity had greater odds of mental distress compared with women who reported being food secure. This association remained even after the inclusion of other factors affecting mental health such as income, SES and presence of children in the home.

Our results also revealed that women with low income were associated with poor mental health, and women from socioeconomically disadvantaged groups were more likely to have mental distress, which accords with previous studies (31).

In the current study, an increase of 1 child was associated with a $23 \%$ increase in the odds of that mother being mentally distressed. A similar finding was reported by Abrahams et al. (3) in South Africa where the odds of having a diagnosis of a major depressive episode were $>2$ times greater in women who had $\geq 3$ children. Additionally, having a husband working abroad had a protective effect on mental health. This was possibly due to money received by women, which improved their material resources and access to food. 


\begin{tabular}{|c|c|c|c|c|}
\hline \multirow[t]{2}{*}{ Food security status } & \multicolumn{4}{|c|}{ Having mental distress ${ }^{a}$} \\
\hline & Crude OR (95\% CI) & $P$ & Adjusted OR (95\% CI) & $\mathbf{P}$ \\
\hline Food secure & 1.0 (reference) & & 1.0 (reference) & \\
\hline Mildly food insecure & $2.38(1.29-4.37)$ & 0.005 & $2.19(1.11-4.31)$ & 0.024 \\
\hline moderately food insecure & $5(3.10-8.09)$ & $<0.001$ & $2.57(1.42-4.65)$ & 0.002 \\
\hline severely food insecure & $29.44(13.38-64.8)$ & $<0.001$ & $12.88(5.16-32.17)$ & $<0.001$ \\
\hline \multicolumn{5}{|l|}{ Income } \\
\hline Able to save money & 1.0 (reference) & & 1.0 (reference) & \\
\hline Meet routine expenses and emergencies & $3.04(1.95-4.73)$ & $<0.001$ & $1.27(0.74-2.18)$ & 0.391 \\
\hline Just meet routine expenses & $8.48(4.67-15.40)$ & $<0.001$ & $2.31(1.13-4.75)$ & 0.022 \\
\hline In debt & $16(7.03-36.44)$ & $<0.001$ & $4.15(1.53-11.28)$ & 0.005 \\
\hline \multicolumn{5}{|l|}{ SES } \\
\hline High & 1.0 (reference) & & 1.0 (reference) & \\
\hline Middle & $4.02(2.35-6.86)$ & $<0.001$ & $2.26(1.2-4.25)$ & 0.012 \\
\hline Low & $5.51(3.13-9.70)$ & $<0.001$ & $2.14(1.06-4.34)$ & 0.034 \\
\hline Very low & $11.75(6.51-21.2)$ & $<0.001$ & $3.39(1.66-6.91)$ & 0.001 \\
\hline \multicolumn{5}{|l|}{ Husband } \\
\hline Present & 1.0 (reference) & & 1.0 (reference) & \\
\hline Working abroad & $0.42(0.28-0.61)$ & $<0.001$ & $0.57(0.36-0.92)$ & 0.022 \\
\hline \multicolumn{5}{|l|}{ Violence } \\
\hline No & 1.0 (reference) & & 1.0 (reference) & \\
\hline Yes & $2.44(1.6-3.74)$ & $<0.001$ & $1.296(0.77-2.18)$ & 0.328 \\
\hline \multicolumn{5}{|l|}{ Type of family } \\
\hline Nuclear & 1.00 (reference) & & 1.00 (reference) & \\
\hline Extended & $0.65(0.43-0.98)$ & 0.041 & $0.71(0.42-1.18)$ & 0.185 \\
\hline No. of children & $1.17(1.02-1.35)$ & 0.027 & $1.23(1.03-1.48)$ & 0.025 \\
\hline
\end{tabular}

N.B. Dependent variable mental distress.

$R^{2}=0.401$.

${ }^{a}$ Hopkins Symptom Check List total score $>1.75$.

$C I=$ confidence interval $; O R=$ odds ratio; $S E S=$ socioeconomic status.

The current study had some limitations: the crosssectional nature of the data limited causal inferences; there was a lack of cooperation by some participants; and responses to the items in HFIAS depended on cultural and social contexts in ways that may not allow comparison of prevalence from this tool among different countries.

\section{Recommendations}

Policy-makers should aim to improve poverty, which would be positively associated with food access. Fundamental reform of the existing economic system is required. It is essential to develop programmes for screening of food insecurity and malnutrition at the household level in order to reach the most-vulnerable people. Screening may be included in national surveys (e.g., Egypt Demographic and Health Survey). Improved targeting of the existing food subsidy system to include more poor households and more-nutritious food items on ration cards, such as meat, eggs and fruits instead of reliance on sugar and oils will be beneficial to the community. Investment in rural populations is a long-term solution through investing in small-scale agriculture and inclusive rural development. Efforts should be directed to empower women economically and socially, especially rural women to protect them and their children from food insecurity.

\section{Conclusion}

Household food insecurity may bring additional stress, contributing to worse mental health. Thus, alleviating HFI should be a priority in order to improve mental health. Both HFI and poor mental health need to be studied further to understand the mediators and moderators of their relationship. Intervention studies designed to mitigate or reverse risks are also needed to determine the best evidence for practice and policy. 


\section{Acknowledgement}

The authors would like to offer their sincere thanks to all the women of Qulubba village, Minia, Egypt, for their participation in the study.

Funding: None.

Competing interests: None declared.

\section{Impact de l'insécurité alimentaire des ménages sur la santé mentale des mères en Égypte}

\section{Résumé}

Contexte: L'insécurité alimentaire entraîne une perturbation des habitudes alimentaires, provoquant la faim ou une mauvaise nutrition; elle est par ailleurs fortement corrélée à une mauvaise santé mentale.

Objectifs: Déterminer l'impact de l'insécurité alimentaire des ménages sur la santé mentale des mères dans une population rurale en Égypte.

Méthodes: La présente étude transversale en milieu communautaire a été menée dans le village de Qulubba, Gouvernorat de Minia. Nous avons interrogé 497 mères qui avaient au moins un enfant, en utilisant les instruments suivants : l'échelle d'insécurité alimentaire des ménages et la liste de contrôle des symptômes de Hopkins-25.

Résultats : Près de $70 \%$ des femmes vivaient dans des foyers où régnait une insécurité alimentaire. Les symptômes d'anxiété et de dépression étaient significativement plus fréquents chez les mères en situation d'insécurité alimentaire. À l'analyse de régression logistique, l'insécurité alimentaire des ménages, le statut socio-économique, le fait que le mari travaillait à l'étranger et le nombre d'enfants étaient des facteurs prédictifs significatifs de la détresse maternelle. Les mères souffrant d'insécurité alimentaire sévère étaient environ 13 fois plus susceptibles de souffrir de détresse mentale que les mères qui se trouvaient en situation de sécurité alimentaire.

Conclusions: L'insécurité alimentaire des ménages est associée à une probabilité accrue de problèmes de santé mentale maternelle. L'étude souligne la nécessité de politiques de réduction de la pauvreté et de programmes de dépistage et de prise en compte de l'insécurité alimentaire. Il est recommandé d'intégrer la santé mentale dans les programmes qui luttent contre l'insécurité alimentaire et fournissent des conseils à ce sujet.

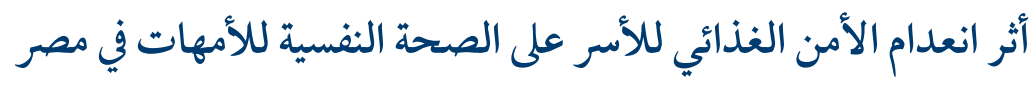

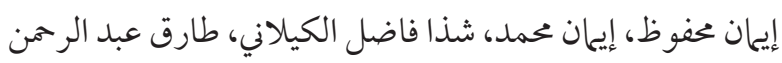

$$
\begin{aligned}
& \text { الخلاصة } \\
& \text { الخلفية: يؤدي انعدام الأمن الغذائي إلى أنماط مضطربة من الأكل أو الجوع أو سوء التغذية ويرتبط ارتباطًا قويًا بسوء الصحة النفسية. }
\end{aligned}
$$

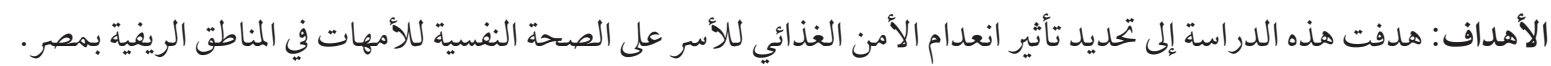

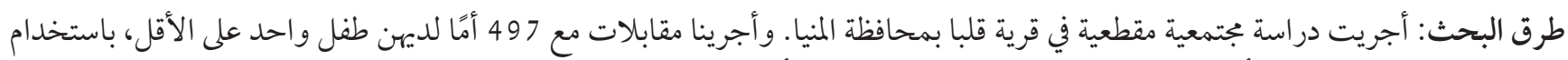

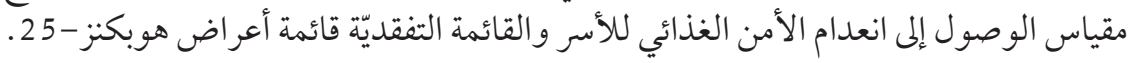

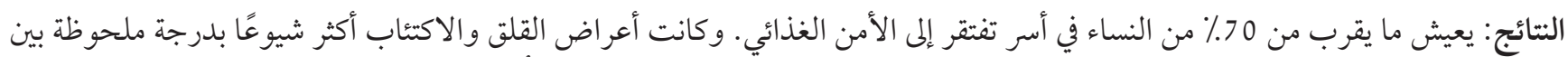

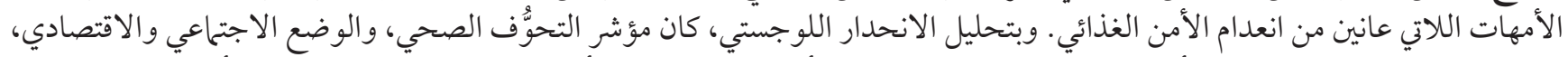

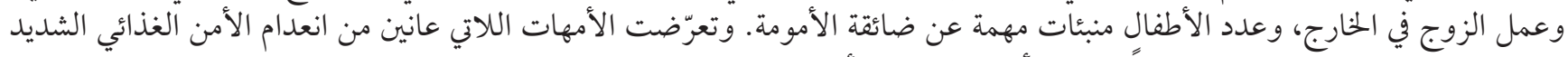

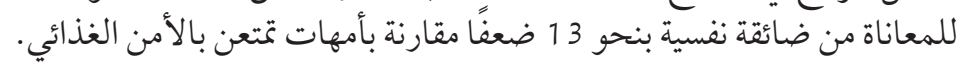

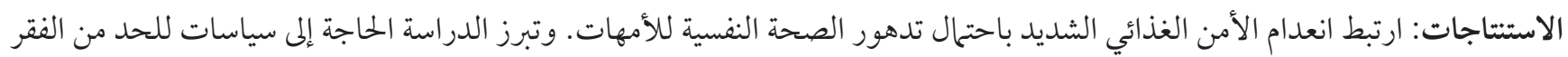

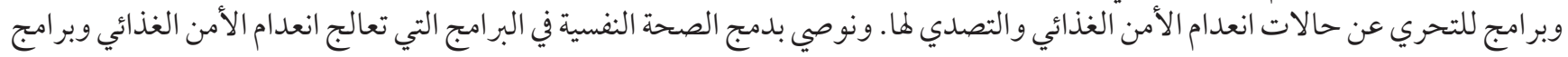

$$
\begin{aligned}
& \text { تقديم المشورة. }
\end{aligned}
$$




\section{References}

1. Rome Declaration on World Food Security. World Food Summit, 13-17 November 1996, FAO, Rome, Italy. Rome: Food and Agricultural Organization of the United Nations; 1996 (wwwfaoorg/docrep/003/w3613e/w3613eoo.htm, accessed 19 December 2020).

2. McGuire S. FAO, IFAD, and WFP. The state of food insecurity in the world 2015: Meeting the 2015 International Hunger Targets: taking stock of uneven progress. Rome: FAO, 2015. Adv Nutr. 2015 Sep;6(5):623-4. https://doi.org/10.3945/an.115.009936 PMID:27352453

3. Abrahams Z, Lund C, Field S, Honikman S. Factors associated with household food insecurity and depression in pregnant South African women from a low socio-economic setting: a cross-sectional study. Soc Psychiatry Psychiatr Epidemiol. 2018 Apr;53(4):363-72. https://doi.org/10.1007/s00127-018-1497-y PMID:29445850

4. Youngmi K, Aely P, Jin H. Is food insecurity associated with depressive symptoms in South Korea? Asian Soc Work Policy Rev. 2017 Feb;11(1):30-9. https://doi.org/10.1111/aswp.12111

5. Jones AD. Food insecurity and mental health status: a global analysis of 149 countries. Am J Prev Med. 2017;53(2):264-73. https:// doi.org/10.1016/j.amepre.2017.04.008

6. Soliman S. Food security and vocational education and training: exploring the links in the Egyptian case. In: Mergos G, Papanastassiou M, editors. Food security and sustainability: investment and financing along agro-food chains. London: Palgrave Macmillan; 2017:193-208.

7. El-Said HM. Investigating impact of Egyptian marco-economic changes on auditors' assessments of audit risk: an empirical study. Cairo University; 2017 (http://erepository.cu.edu.eg/index.php/COMM-Conf/article/view/7420/7271, accessed 19 December 2020).

8. Von Elm E, Altman DG, Egger M, Pocock SJ, Gøtzsche PC, Vandenbroucke JP. The Strengthening the Reporting of Observational Studies in Epidemiology (STROBE) statement: guidelines for reporting observational studies. J Clin Epidemiol. 2008 Apr;61(4):344-9. https://doi.org/10.1016/j.jclinepi.2007.11.008 PMID:18313558

9. Poverty indicators according to the Egyptian Household Income, Consumption and Expenditure Survey (HIECS, 2012/2013). Cairo: Central Agency For Public Mobilization \& Statistics; 2013.

10. El-Gilany A, El-Wehady A, El-Wasify M. Updating and validation of the socioeconomic status scale for health research in Egypt. East Mediterr Health J. 2012 Sep;18(9):962-8. https://doi.org/10.26719/2012.18.9.962 PMID:23057390

11. Fahmy S, El-Sherbini A. Determining simple parameters for social classifications for health research. Bull High Inst Public Health. 1983;13(5):95-108.

12. Coates J, Swindale A, Bilinsky P. Household Food Insecurity Access Scale (HFIAS) for measurement of food access: indicator guide. Washington, DC: Food and Nutrition Technical Assistance Project, Academy for Educational Development; 2007 (http:// www.fao.org/fileadmin/user_upload/eufao-fsi4dm/doc-training/hfias.pdf, accessed 19 December 2020).

13. Naja F, Hwalla N, Fossian T, Zebian D, Nasreddine L. Validity and reliability of the Arabic version of the Household Food Insecurity Access Scale in rural Lebanon. Public Health Nutr. 2015 Feb;18(2):251-8. https//doi.org/10.1017/S1368980014000317 PMID:24702865

14. Derogatis LR, Lipman RS, Rickels K, Uhlenhuth EH, Covi L. The Hopkins Symptom Checklist (HSCL): a self report symptom inventory. Behav Sci. 1974 Jan;19(1):1-15. https://doi.org/10.1002/bs.3830190102 PMID:4808738

15. Bordignon G. The status of poverty and food security in Egypt: analysis and policy recommendations. Cairo: World Food Programme; 2013 (https://documents.wfp.org/stellent/groups/public/documents/ena/wfp257467.pdf, access 19 December 2020).

16. Kukrety N. Poverty, inequality and social protection in Lebanon. Beirut: Oxfam International Issam Fares Institute of the American University, Beirut; 2016 (https://www.oxfam.org/en/research/poverty-inequality-and-social-protection-lebanon, accessed 19 December 2020).

17. Chen S, Schreiner M. Simple Poverty Scorecard Poverty-Assessment Tool: Vietnam (http://www.simplepovertyscorecard.com/ VNM_2006_ENG.pdf, accessed 19 December 2020).

18. GIEWS - Global Information and Early Warning System [website]. Rome: Food and Agriculture Organisation of the United Nations; 2017 (www.fao.org/3/a-i8278e.pdf, accessed 19 December 2020).

19. Saaka M, Osman SM. Does household food insecurity affect the nutritional status of preschool children aged 6-36 months? Int J Popul Res. 2013;2013: Article ID 304169. https://doi.org/10.1155/2013/304169

20. Abdurahman A, Mirzaei K, Dorosty A, Rahimiforoushani A, Kedir H. Household food insecurity may predict underweightand wasting among children aged 24-59 months. Ecol Food Nutr. 2016 Sep-Oct;55(5):456-72. https://doi.org/10.1080/03670244.2016.1 207069 PMID:27467901

21. Ihab AN, Rohana AJ, Wan Manan WM, Wan Suriati WN, Zalilah MS, Mohamed Rusli A. Nutritional outcomes related to household food insecurity among mothers in rural Malaysia. J Health Popul Nutr. 2013 Dec;31(4):480-9. https://doi.org/10.3329/jhpn. v31i4.20031 PMID:24592589

22. Abraham TT, Tsegaye DG, Berhanu KS, Mulugeta YK. Household food insecurity and associated factors among households in Wolaita Sodo town, 2015. Agric Food Secur. 2017;6(1):19. https://doi.org/10.1186/s40066-017-0098-4 
23. Weigel MM, Armijos RX, Racines M, Cevallos W. Food insecurity is associated with undernutrition but not overnutrition in Ecuadorian women from low-income urban neighborhoods. J Environ Public Health. 2016;2016:Article ID 8149459. https://doi. org/10.1155/2016/8149459 PMID:27110253

24. El-Amin AM, Mahfouz EM, Seedhom AE, Mohamed ES. The effect of maternal mental health on child nutritional status in El-Minia City. MJMR. 2014;25(1):83-8.

25. Hromi-Fiedler A, Bermudez-Millan A, Segura-Perez S, Perez-Escamilla R. Household food insecurity is associated with depressive symptoms among low-income pregnant Latinas. Matern Child Nutr. 2011 Oct;7(4):421-30. https://doi.org/10.1111/j.17408709.2010.00266.x PMID:20735732

26. Ribeiro-Silva RdC, Fiaccone RL, Barreto ML, Santana MLP, Chaves dos Santos SM, Pereira da Conceição-Machado ME et al. The association between intimate partner domestic violence and the food security status of poor families in Brazil. Public Health Nutr. 2015 May;19(7):1305-11. https://doi.org/10.1017/S1368980015002694 PMID:26411418

27. Martin MS, Maddocks E, Chen Y, Gilman SE, Colman I. Food insecurity and mental illness: disproportionate impacts in the context of perceived stress and social isolation. Public Health. 2016 Mar;132:86-91. https://doi.org/10.1016/j.puhe.2015.11.014 PMID:26795678

28. Ricks JL, Cochran SD, Arah OA, Williams JK, Seeman TE. Food insecurity and intimate partner violence against women: results from the California Women's Health Survey. Public Health Nutr. 2016 Apr;19(5):914-23. https:/doi.org/10.1017/S1368980015001986 PMID:26096652

29. Garg A, Toy S, Tripodis Y, Cook J, Cordella N. Influence of maternal depression on household food insecurity for low-income families. Acad Pediatr. 2015 May-Jun;15(3):305-10. https://doi.org/10.1016/j.acap.2014.10.002 PMID: =25454368

30. Corman H, Curtis MA, Noonan K, Reichman NE. Maternal depression as a risk factor for children's inadequate housing conditions. Social Science \& Medicine. 2016 Jan;149:76-83. https://doi.org/10.1016/j.socscimed.2015.11.054 PMID:26708243

31. Rani D, Singh J, Acharya D, Paudel R, Lee K, Singh S. Household Food Insecurity and Mental Health Among Teenage Girls Living in Urban Slums in Varanasi, India: A Cross-Sectional Study. Int J Environ Res Public Health. 2018 Jul 26;15(8):1585. https://doi. org/10.3390/ijerph15081585 PMID:30049971

32. Jebena MG, Lindstrom D, Belachew T, et al. Food insecurity and common mental disorders among Ethiopian youth: structural equation modeling. PloS One. 2016 Nov 15;11(11):e0165931. https://doi.org/10.1371/journal.pone.0165931 PMID:27846283

33. Huddleston-Casas C, Charnigo R, Simmons LA. Food insecurity and maternal depression in rural, low-income families: a longitudinal investigation. Public Health Nutr. 2009 Aug;12(8):1133-40. https://doi.org/10.1017/S1368980008003650 PMID:18789167

34. Shaikh AK, Pearce B, Yount KM. Effect of enabling resources and risk factors on the relationship between intimate partner violence and anxiety in ever-married women in Minya, Egypt. J Fam Viol. 2017;32:13-23. https://doi.org/10.1007/s10896-016-9848-5 